\title{
Molecular cloning and characterization of a thioredoxin from Taiwanofungus camphorata
}

\author{
Yu-Ting Chen ${ }^{2 \dagger}$, Pin-Feng Hong ${ }^{1 \dagger}$, Lisa Wen ${ }^{3 \dagger}$ and Chi-Tsai Lin ${ }^{1 *}$
}

\begin{abstract}
Background: Thioredoxin (Trx) is reduced by thioredoxin reductase. Trx is used in ribonucleoide reduction, assimilatory sulfate reduction, in modulation of protein sulfhydryl groups, and refolding proteins.

Results: A TcTrx (Tc: Taiwanofungus camphorata) CDNA (640 bp, GenBank AY838902.1) encoding a putative thioredoxin (Trx) of 135 amino acid residues with calculated molecular mass of $16.17 \mathrm{kDa}$ was cloned from Taiwanofungus camphorata. The deduced amino acid sequence containing a motif (Cys-Gly-Pro-Cys) that is highly conserved among the reported Trxs. A three dimensional structural model of the TcTrx has been created based on the known structure of Malassezia sympodialis Trx (MsTrx, PDB ID: 2j23). To characterize the TcTrx, the codon optimized coding region was subcloned into an expression vector and transformed into Saccharomyces cerevisiae. The recombinant His8-tagged TcTrx was expressed and purified by Ni affinity chromatography. The purified enzyme showed a band of approximately $32 \mathrm{kDa}$ (expected dimeric form) on a 12\% SDS-PAGE. The molecular mass determined by MALDI-TOF is $33.16 \mathrm{kDa}$ which suggests that the purified enzyme is a dimeric enzyme. Furthermore, the enzyme exhibited TcTrx activity via insulin assay. The Michaelis constant $\left(K_{M}\right)$ value for insulin was $3.78 \times 10^{-2} \mathrm{mM}$. The enzyme's half-life of deactivation was 13 min at $45^{\circ} \mathrm{C}$. The enzyme was most active at $\mathrm{pH} 7$.

Conclusions: A three dimensional structural model of T. camphorata Trx based on its TcTrx cDNA sequence. The active form of the TcTrx has been successfully expressed in yeast. The enzyme possesses Trx activity and is capable of reduction of disulfide bonds during the formation of newly synthesized proteins.
\end{abstract}

Keywords: Taiwanofungus camphorata; Thioredoxin (Trx); Three-dimension structural model; Insulin

\section{Background}

Taiwanofungus camphorata (T. camphorata) is a valued mushroom found only in the forests of Taiwan. It has been used for centuries as health food, among others (Ao et al. 2009). T. camphorata has been shown to have anti-inflammatory properties (Hsieh et al. 2010). The active compounds identified from the fruiting bodies of $T$. camphorata in a submerged culture are benzenoids, diterpenes, maleic and succinic acid derivatives, polysaccharides, steroids, and triterpenoids (Ao et al. 2009). It can be obtained as health supplements formulated from the mass of T. camphorata from the artificial cultivation by an Asian

\footnotetext{
* Correspondence: B0220@mail.ntou.edu.tw

${ }^{\dagger}$ Equal contributors

${ }^{1}$ Department of Bioscience and Biotechnology and Center of Excellence for the Oceans, National Taiwan Ocean University, 2 Pei-Ning Rd, Keelung 202, Taiwan

Full list of author information is available at the end of the article
}

Nova Biotechnology Inc (http://www.asian-bio.com/) at a high market value. Many studies were aimed to find the exact bioactive compounds of the mushroom (Ao et al. 2009). In order to search for physiologically active components including antioxidant enzymes, we have established an expressed sequence tag (EST) from the fruiting bodies of T. camphorata. Based on the established EST, several antioxidant enzymes including a 2-Cys peroxiredoxin (Huang et al. 2007), a catalase (Ken et al. 2008), a dithiol glutaredoxin (Ken et al. 2009), a 2-Cys peroxiredoxin isozyme (Liau et al. 2010), a monothiol glutaredoxin (Ken et al. 2011), a nitroreductase (Chen et al. 2012), a peroxiredoxin (Huang et al. 2014) and an aryl-alcohol dehydrogenase (Ken et al. 2014) have been cloned and characterized. This encourages us further to search for active components from the established EST of T. camphorata for potential health food applications.

Thioredoxin ( $\operatorname{Trx})$ is reduced by thioredoxin reductase with NADPH as the hydrogen donor. Trx is used in

\section{至 Springer}


refolding proteins (( $\mathrm{Li}$ and Churchich 1997), in modulation of protein sulfhydryl groups (Buchanan et al. 1994), and phage assembly (Russel and Mode 1986). Here, we report a three dimensional structural model of Taiwanofungus camphorata thioredoxin based on its sequence. The coding sequence of the TcTrx cDNA was introduced into an $S$. cerevisiae expression system and the active enzyme purified and characterized its properties.

\section{Methods}

\section{Isolation of TcTrx cDNA}

We have previously established an EST database from fruiting bodies of $T$. camphorata and sequenced all clones with insert size greater than $0.4 \mathrm{~kb}$ (data not shown). The identity of a Trx cDNA clone was assigned by comparing the inferred amino acid sequence in various databases using the basic local alignment search tool (BLAST) (http://www.ncbi.nlm.nih.gov/blast/Blast.cgi). The Trx cDNA fragment was subcloned into $\mathrm{pCR}^{\oplus} 4-\mathrm{TOPO}^{\circ}$ (invitrogen, CA) vector and transformed into $E$. coli TOPO10. The nucleotide sequence of the insert was determined in both strands. Sequence analysis revealed that the Trx cDNA covered an open reading frame of a putative Trx cDNA (640 bp, GenBank AY838902.1).

\section{Bioinformatics analysis of TcTrx}

The BLAST program was used to search homologous protein sequences in the nonredundant database (NRDB) at the National Center for Biotechnology Information, National Institutes of Health (http://www.ncbi.nlm.nih.gov/). Multiple alignments were constructed using ClustalW2 program. Protein secondary structure was predicted by SWISS-MODEL program and represented as $\alpha$ helices and $\beta$ strands. A three dimensional structural model of TcTrx was created by SWISS-MODEL (Arnold et al. 2006) (http://swissmodel.expasy.org/) based on the known crystal structure of Malassezia sympodialis Trx (MsTrx, PDB ID: 2j23).

\section{Subcloning of TcTrx cDNA into an expression vector}

TcTrx cDNA was subcloned into an E. coli and yeast expression vector, respectively. The coding region of the TcTrx cDNA was amplified using gene specific flanking primers. The 5' upstream primer contains Eco RI recognition site (5'GAA TTC GAT GTT ATC TTC GCT TGC ATC C3') and the 3' downstream primer contains Eco RI recognition site (5'GAA TTC GCG AGG CCC TGG ATG AG3'). Using $0.2 \mu \mathrm{g}$ of TcTrx cDNA as a template, and 10 pmole of each $5^{\prime}$ upstream and $3^{\prime}$ downstream primers, a 405 bp fragment encoding the putative mature TcTrx gene was amplified by PCR. The fragment was ligated into $\mathrm{pCR}^{\mathrm{O}} 4-\mathrm{TOPO}^{\mathrm{O}}$ and transformed into E. coli. The recombinant plasmid was isolated and digested with Eco RI. The digestion products were separated on a $1.0 \%$ agarose gel. The 405 bp insert DNA was gel purified and subcloned into Eco RI site of pET-20b(+) expression vector (Novagen, Darmstadt, Germany). The recombinant DNA was then transformed into E. coli C43 (DE3). However, the recombinant protein was not expressed in the $E$. coli expression system. We then subcloned the gene into the Eco RI site of the pYEX-S1 expression vector (Clontech, Mountain View, CA, USA) and introduced into Saccharomyces cerevisiae (trp ${ }^{-}$ura $^{-}$), The recombinant protein was still not expressed in the Saccharomyces cerevisiae expression system. We decided to optimize the TcTrx DNA sequenced based on the yeast codon usage table (The codons were optimized by using the Codon Optimization Tool provided by the Integrated DNA Technologies (http://sg.idtdna.com/CodonOpt) with codon usage table of Saccharomyces cerevisiae. The GenScript Codon Usage Frequency Table Tool was used as the reference for yeast usage table. The optimized gene was custom synthesized by Genomics company, Taiwan. The optimized sequence is shown in Figure 1 in red. It was subcloned into a pET-20b(+) expression vector and the recombinant DNA transformed into $E$. coli C43(DE3). The recombinant protein was still not expressed in the $E$. coli expression system. We then re-amplified the codonoptimized pET-20b(+)-TcTrx DNA using two gene-specific primers: the $5^{\prime}$ upstream primer contained Eco RI recognition site (5'GAA TTC GAT GTT ATC TTC GCT TGC ATC C3') and the $3^{\prime}$ downstream primer contained a His8-tag and Eco RI recognition site (5' GAATTC GAG ACG TCA GTG GTG GTG GTG GTG GTG GTG GTG3'). Using the $0.2 \mu \mathrm{g}$ optimized recombinant DNA of pET-20b(+)-TcTrx as a template, and 10 pmole of each $5^{\prime}$ upstream and 3' downstream primers, a $0.4 \mathrm{~kb}$ fragment was amplified by PCR. The fragment was ligated into $\mathrm{pCR}^{\mathrm{O}} 4-\mathrm{TOPO}^{\mathrm{O}}$ and transformed into E. coli. The recombinant plasmid was isolated and digested with Eco RI. The digestion products were separated on $1.0 \%$ agarose gel. The $0.4 \mathrm{~kb}$ insert DNA was gel purified and subcloned into the Eco RI site of the pYEX-S1 expression vector and introduced into Saccharomyces cerevisiae (trp ${ }^{-}$ura $^{-}$). The transformed yeast cells were selected by YNBDT $(0.17 \%$ yeast nitrogen base, $0.5 \%$ ammonium sulfate, and $2 \%$ glucose) agar plates containing $20 \mu \mathrm{g} \operatorname{Trp} / \mathrm{mL}$. The presence of TcTrx cDNA in the selected transformants was verified by PCR using gene-specific flanking primers. The recombinant TcTrx protein was expressed in yeast in YPD medium $(1 \%$ yeast extract, $2 \%$ peptone, $2 \%$ glucose). Expression of the functional recombinant TcTrx was analyzed by enzyme activity assay.

\section{Expression and purification of the recombinant TcTrx}

The yeast transformant containing the TcTrx gene was grown at $30^{\circ} \mathrm{C}, 170 \mathrm{rpm}$ in $100 \mathrm{~mL}$ of YPD medium for 


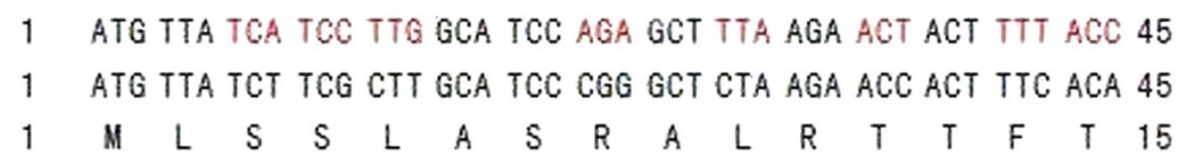

46 ACA CAA AAT GTA TTG AAG AGA GGT TTC CAC TCA TCC ATC AGA AGA 90

46 ACA CAA AAC GTG CTG AAA AGG GGC TTC CAC TCA AGC ATA CGA CGG 90

$\begin{array}{lllllllllllllllll}16 & T & Q & N & V & L & K & R & G & F & H & S & S & I & R & R & 30\end{array}$

91 AAT GAA CAA TTT TTG AAT GCT AAC GCA GAA RCT TTC TCT AAG GGA 135

91 AAT GAG CAG TTC TTG AAT GCA AAC GCG GAG ACA TTT TCA AAG GCC 135

$\begin{array}{lllllllllllllllll}31 & N & E & Q & F & L & N & A & N & A & E & T & F & S & K & A & 45\end{array}$

136 ATC TCA AAC GAA GAT AAC GTT GTC TTG GTT GAT TTT TAT GCC GAC 180 136 ATC TCG AAT GAG GAT AAC GTC GTA CTG GTC GAC TTT TAT GCA GAC 180 $\begin{array}{llllllllllllllllll}46 & \text { I } & S & N & E & D & N & V & V & L & V & D & F & Y & A & D & 60\end{array}$

181 TGG TGT GGT CCA TGC AAA GTC ATT TCC CCT ATC TTC CAA AAG TTG 225 181 TGG TGT GGC CCA TGC AAG GTC ATC TCG CCC ATC TTC CAG AAG CTT 225 $\begin{array}{lllllllllllllllll}61 & W & C & G & P & C & K & V & \text { I } & \text { S } & P & \text { I } & F & Q & K & L & 75\end{array}$

226 TTC GAA CAA TTC AGT CAT GCT GAT TTC TAC AAG GTA GAC GTT GAT 270 226 TTT GAG CAG TTT TCG CAC GCG GAT TTC TAC AAG GTC GAC GTG GAC 270 $\begin{array}{lllllllllllllllll}76 & F & E & O & F & S & H & A & D & F & Y & K & V & D & V & D & 90\end{array}$

271 GAC CAA CAA GAT ATC TCT CAA GAA GTC GGT ATT AGA GCC ATG CCA 315 271 GAC CAG CAG GAC ATC TCC CAG GAA GTC GGC ATT CGT GCG ATG CCC 315 $\begin{array}{lllllllllllllllll}91 & D & Q & 0 & D & \text { I } & S & 0 & E & V & G & \text { I } & R & A & M & P & 105\end{array}$ 316 ACA TTT GTA GCT TTC AAA AAC GGT TCC AAG TTG AAG GAA ATC GTA 360 316 ACC TTC GTG GCT TTC AAG AAC GGC TCG AAG CTC AAA GAG ATC GTA 360

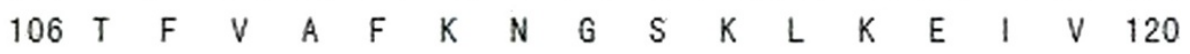

361 GGT GCT RAT CCA TCC GGT TTA CAA GAA TTG ATA CAA GGT TTG GCT 405 361 GGC GCT AAT CCG AGT GGC CTT CAG GAA CTC ATC CAG GGC CTC GCG 405 $\begin{array}{lllllllllllllllll}121 & G & A & N & P & S & G & L & Q & E & L & \text { I } & Q & G & \text { L } & \text { A } & 135\end{array}$

Figure 1 Nucleotide sequences of TcTrx CDNA and its codon usage optimization based on the yeast codon usage table. The codon optimization of TcTrx was shown above with red codon.

$18 \mathrm{~h}$. The cells were harvested and the soluble proteins extracted in PBS (phosphate buffer saline) with glass beads as described previously (Ken et al. 2005). The recombinant TcTrx was purified by Ni-NTA affinity chromatography (elution buffer: $1 \times$ PBS/5\% glycerol/1 mM DTT containing 20-250 mM imidazole) according to manufacturer's instruction (Qiagen). The purified protein was analyzed by a $12 \%$ SDS-PAGE followed by staining with Coomassie Brilliant Blue R-250 and destaining with $10 \%$ acetic acid/10\% 


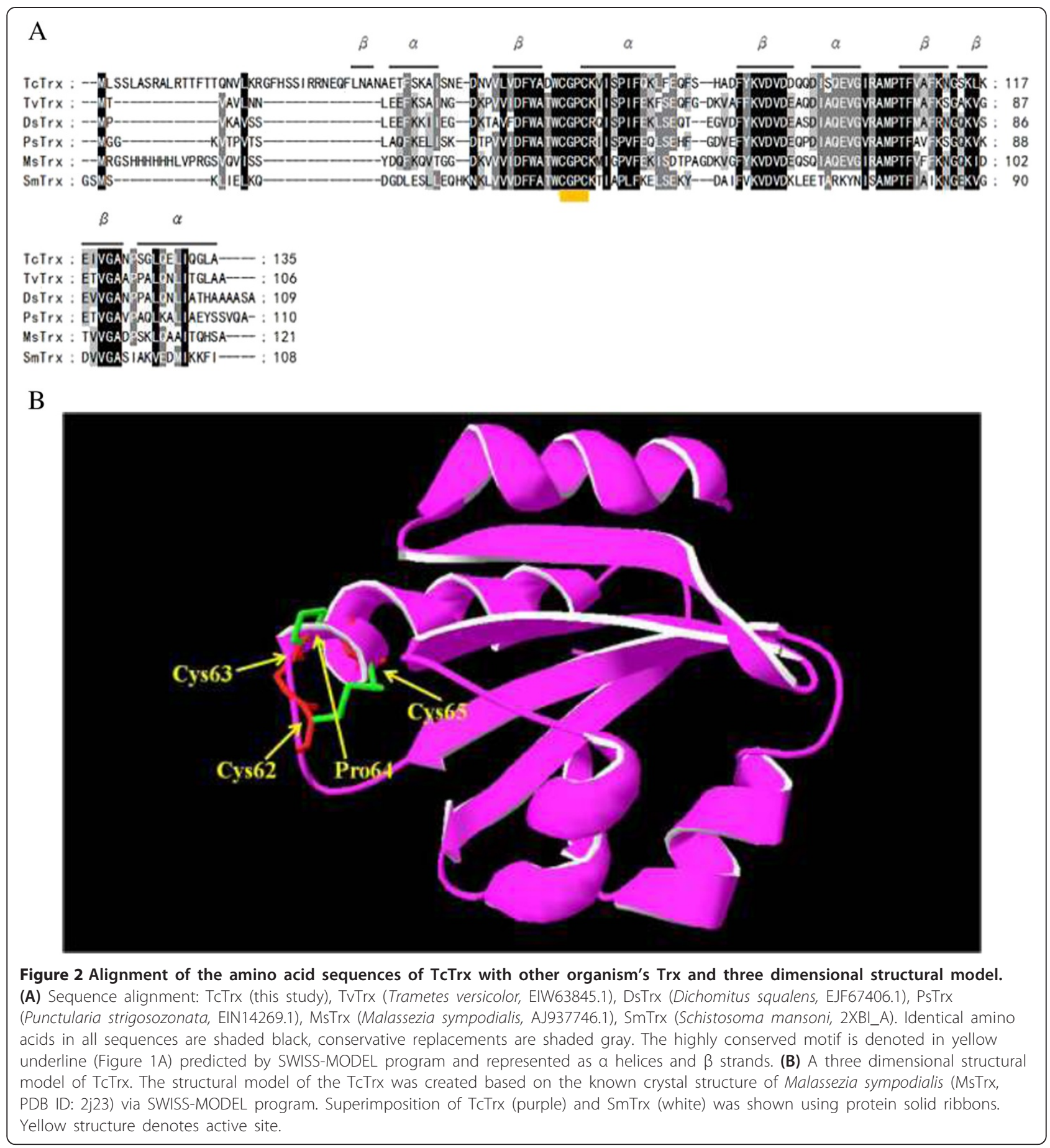

methanol. The purified protein was pooled, desalted, and buffer exchanged using Amicon ultra centrifugal filter unit (5000 MWCO). The exchanged buffer exchanged was $0.01 \times \mathrm{PBS} / 0.01 \mathrm{mM}$ DTT/2.5 mM imidazole $/ 0.1 \%$ glycerol. The final recombinant TcTrx protein concentration was determined by a Bio-Rad Protein Assay Kit (Richmond, CA). For storage, one volume of glycerol was added to the purified protein and stored at $-20^{\circ} \mathrm{C}$ for further analysis.

\section{Molecular mass analysis via JOEL MALDI-TOF}

The purified recombinant TcTrx $(0.82 \mu \mathrm{g} / \mu \mathrm{L})$ was prepared in $0.01 \times$ PBS containing $0.01 \mathrm{mM}$ DTT, $2.5 \mathrm{mM}$ imidazole and $0.1 \%$ glycerol. The sample $(5 \mu \mathrm{L})$ was 


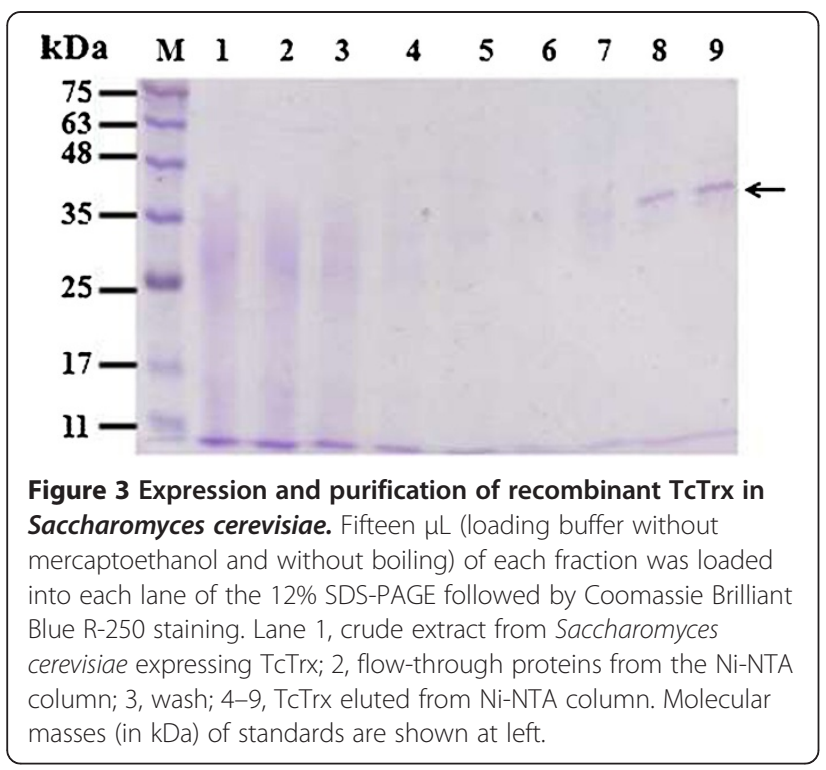

used for molecular mass determination using an MALDI-TOF mass spectrometer (JMS-S3000, Japan).

\section{TcTrx activity assay}

Trx activity was assayed by the method of Holmgren (Holmgren and Reichard 1967; Holmgren 1979a, b) using the insulin precipitation assay which was monitored by a spectrophotometric assay of the increase in turbidity at $650 \mathrm{~nm}$. The reaction mixture $(200 \mu \mathrm{L})$ at $25^{\circ} \mathrm{C}$ contained $0.1 \mathrm{M}$ potassium phosphate ( $\mathrm{pH}$ 7.0), 2 mM EDTA, $0.33 \mathrm{mM}$ DTT, $15 \mathrm{mM}$ NADPH, $0.025 \mathrm{mM}$ insulin and $1.0 \mu \mathrm{g}$ TcTrxR (thioredoxin reductase from T. camphorata, Huang et al. 2010). The reaction was started by the addition
Table 1 Kinetic characterization of TcTrx and that from other sources

\begin{tabular}{lllll}
\hline Protein & Substrate & $\boldsymbol{K}_{\mathbf{m}}(\mathbf{m M})$ & $\boldsymbol{k}_{\text {cat }}$ & $\boldsymbol{k}_{\text {cat }} / \boldsymbol{K}_{\mathbf{m}}$ \\
\hline TcTrx & insulin & $3.7 \times 10^{-2}$ & 1.2 & $3.1 \times 10^{1}$ \\
E. coli Trx & insulin & $1.1 \times 10^{-2}$ & & \\
Dv Trx & insulin & $6.3 \times 10^{-3}$ & & \\
Dr Trx & insulin & $5.7 \times 10^{-3}$ & 1.1 & $1.9 \times 10^{2}$ \\
\hline
\end{tabular}

Values are from TcTrx (this study), Escherichia coli Trx (E. coli Trx) (Holmgren 1979a), Desulfovibrio vulgaris Trx (Dv Trx) (Pieulle et al. 2011) and Deinococcus radiodurans $\operatorname{Trx}$ (Dr Trx) (Obiero et al. 2010).

of $1.0 \mu \mathrm{g}$ TcTrx $(0.41 \mu \mathrm{g} / \mu \mathrm{L})$. The reaction was followed by the increase in $A_{650}$ due to insulin precipitation on reduction.

\section{Kinetic studies}

The kinetic properties of the $\operatorname{Tc} \operatorname{Trx}(1.0 \mu \mathrm{g})$ was determined by varying the concentrations of insulin $(0.025$ $0.055 \mathrm{mM}$ ). The change in absorbance at $650 \mathrm{~nm}$ was recorded between 30 and $60 \mathrm{sec}$. The $K_{\mathrm{M}}, \mathrm{V}_{\max }$ and $k_{\text {cat }}$ were calculated from Lineweaver-Burk plots.

\section{Enzyme characterization}

The TcTrx enzyme was tested for stability in terms of its activity under various conditions. Aliquots of the TcTrx sample $(1.0 \mu \mathrm{g})$ were treated as follows: (1) Thermal effect. Each enzyme sample $(1.0 \mu \mathrm{g})$ was heated at 40,50 , or $60^{\circ} \mathrm{C}$ for $5 \mathrm{~min}$. Then samples were checked for TcTrx activity: $80 \%$ residual activity at $40^{\circ} \mathrm{C}$ treatment, $40 \%$ residual activity at $50^{\circ} \mathrm{C}$ treatment. Therefore, we choose at $45^{\circ} \mathrm{C}$ heating to this enzyme effect, each enzyme sample $(1.0 \mu \mathrm{g})$ was heated at $45^{\circ} \mathrm{C}$ for $2,4,8$, $16 \mathrm{~min}$. (2) pH effect. Each enzyme sample $(1.0 \mu \mathrm{g})$ was

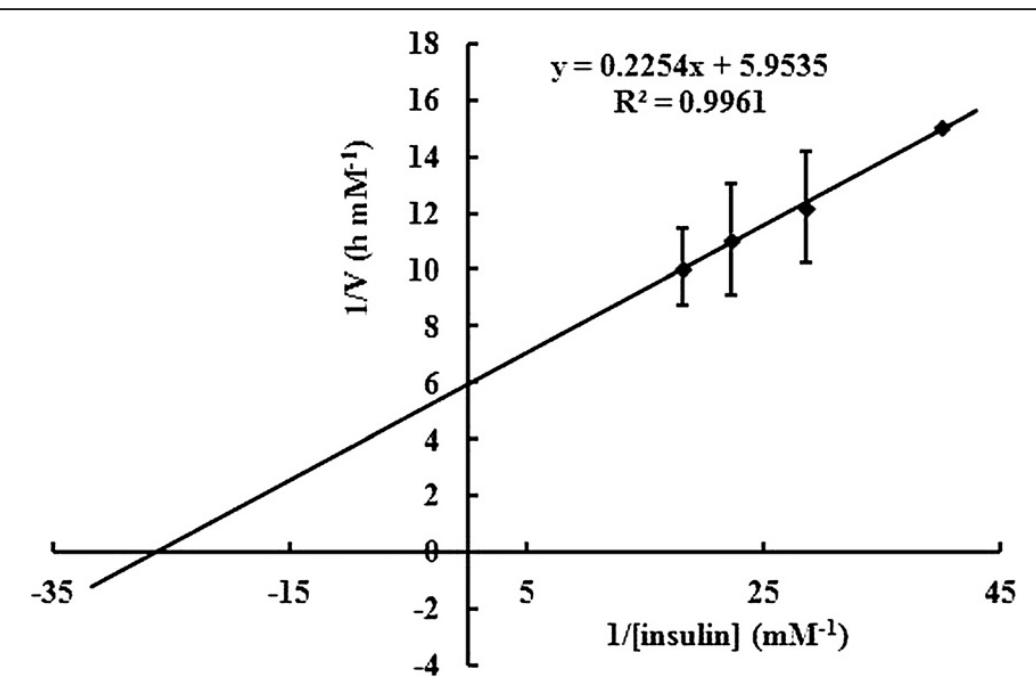

Figure 4 Double-reciprocal plot of varying insulin on TcTrx activity. The initial rate of the enzymatic reaction was measured with change in absorbance at $650 \mathrm{~nm}$ between 30 and $60 \mathrm{sec}$ with the insulin varied from $0.025 \sim 0.055 \mathrm{mM}$. The $K_{M} k_{\text {cat }}$ and $k_{\text {cat }} / K_{M}$ were calculated from Lineweaver-Burk plots. 


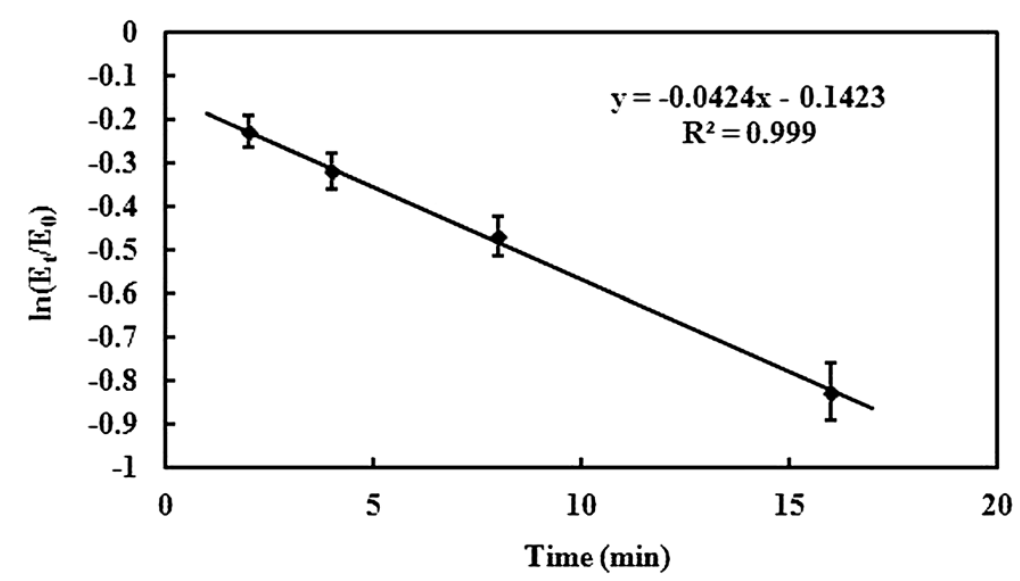

Figure 5 Effect of temperature on the purified TcTrx. The enzyme sample $(1.0 \mu \mathrm{g})$ was heated at $45^{\circ} \mathrm{C}$ for $2,4,8,16$ min. At the end of each treatment, samples were assayed for TcTrx activity at pH 7.0.

adjusted to desired $\mathrm{pH}$ by adding a half volume of buffer with different pHs: $0.2 \mathrm{M}$ citrate buffer $(\mathrm{pH} 4.0), 0.2 \mathrm{M}$ phosphate buffer (pH 6.0, 7.0 or 8.0) or 0.2 M CAPS buffer (pH 10.0). Each sample was incubated at $37^{\circ} \mathrm{C}$ for $30 \mathrm{~min}$. At the end of each treatment, samples were checked for TcTrx activity by insulin precipitation assay at $\mathrm{pH} 7$.

\section{Results and discussion}

A three dimensional structural model of Taiwanofungus camphorata thioredoxin based on its TcTrx CDNA sequence

A putative TcTrx cDNA (640 bp) clone was identified on the basis of the consensus pattern and sequence homology to other published Trxs in NCBI database. The entire coding region of TcTrx cDNA is $405 \mathrm{bp}$ and the deduced protein consists of 135 amino acid residues with a calculated molecular mass of $16.2 \mathrm{kDa}$ (accession no. GenBank AY838902.1). The TcTrx gene was optimized based on yeast codon usage table as shown Figure 1 red color codon. Figure 2 shows the optimal alignment of the amino acid sequences of the TcTrx with five selected Trx sequences from other sources. This TcTrx shared 63\% similarity with TvTrx (Trametes versicolor, accession no. EIW63845.1), 62\% similarity with DsTrx (Dichomitus squalens, accession no. EJF67406.1), 58\% similarity with PsTrx (Punctularia strigosozonata, accession no. EIN14269.1), 57\% similarity with MsTrx (Malassezia sympodialis, accession no. AJ937746.1, PDB ID: 2j23), and $42 \%$ similarity with SmTrx (Schistosoma mansoni, accession no. 2XBI_A). The deduced amino acid sequence containing highly conserved active site motif $\left(\mathrm{Cys}^{62}\right.$-Gly-Pro-Cys ${ }^{65}$ ) (Limacher, et al. 2007). The two Cys residues are the key to the ability of thioredoxin to reduce other proteins. A three dimensional structural model of the TcTrx (purple) has been created based on the known structure of Malassezia sympodialis Trx

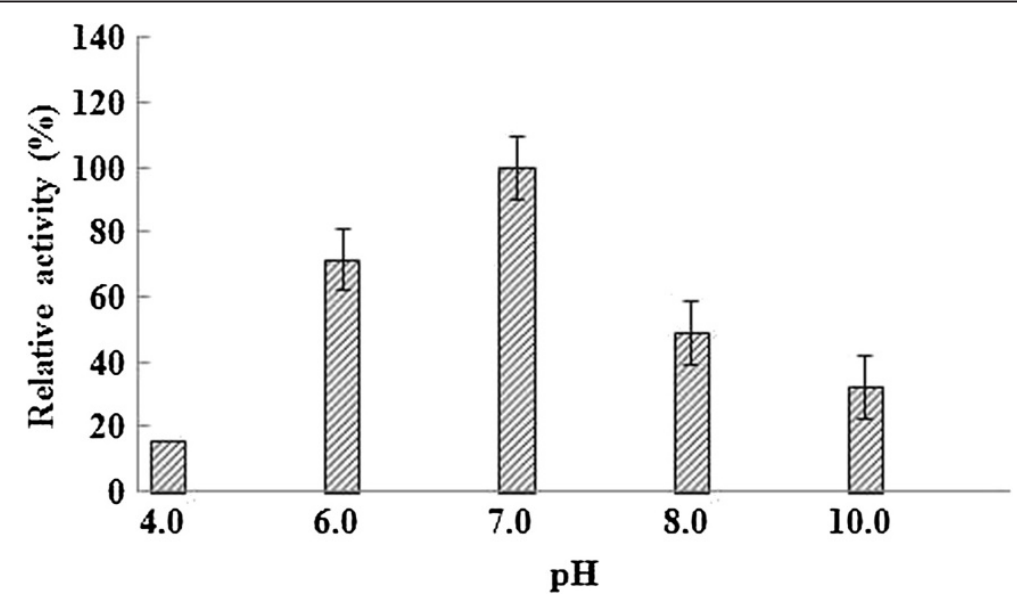

Figure 6 Effect of pH on the purified TcTrx. Aliqouts of the enzyme sample were incubated with different pH buffers at $37^{\circ} \mathrm{C}$ for $30 \mathrm{~min}$ and then assayed for TcTrx activity. Data are means of three experiments. 
(MsTrx, PDB ID: 2j23). The RMSD is $0.95 \AA$. The highly conserved active motif is denoted in yellow underline (Figure 2A). The secondary structure, predicted by SWISS-MODEL program, showed $4 \alpha$ helices and $6 \beta$ strands. Superimposition with SmTrx (PDB ID: 2XBI, white) was shown using protein solid ribbons. Putative active residues are shown in yellow (Figure 2B).

\section{Expression and purification of the recombinant optimized TcTrx}

The optimized coding region for the TcTrx (405 bp) was amplified by PCR and subcloned into an expression vector, pYEX-S1 as described in the Materials and Methods. Positive clones were verified by DNA sequence analysis. The recombinant TcTrx was expressed, and the proteins were analyzed by a $12 \%$ SDS-PAGE in the absence of reducing agent and without boiling (Figure 3). The recombinant TcTrx was expressed as a $\mathrm{His}_{8}$-tagged fusion protein and was purified by affinity chromatography with nickel chelating Sepharose. A major band with molecular mass of $\sim 35 \mathrm{kDa}$ (expected size of TcTrx dimer) was detected in Ni-NTA eluted fractions by SDS-PAGE (Figure 3, lanes 8-9). Analysis of the TcTrx by MALDI-TOF MS confirms the presence of a single protein with molecular mass of $33154 \mathrm{Da}$. This indicates that the enzyme is predominantly dimeric in nature. As shown in Figure 2, from the point of the structure that Cys62 and Cys65, we assume that the Trx favors formation of dimers through intermolecular disulfide linkages. This assumption is supported by our SDS-PAGE analysis of the purified protein in the absence of $\beta$-mercaptoethanol, the dimeric form is predominant (see Figure 3, lanes 8-9). The dimers may be linked by two disulfide bonds between Cys62-Cys65 and Cys65Cys62, or between Cys62-Cys62 and Cys65-Cys65. The dimers may also be linked by one disulphide bond between Cys62 and Cys65, or Cys62-Cys62, or Cys65-Cys65 (Chae et al. 1994; Liau et al. 2010). The yield of the purified $\mathrm{His}_{8-}$ tagged TcTrx was $82 \mu \mathrm{g}$ from $100 \mathrm{~mL}$ of culture. Functional TcTrx was detected by activity assay as describe below.

\section{Kinetic studies of the purified TcTrx}

As shown in Figure 4, the Lineweaver-Burk plot of the velocity $(1 / \mathrm{V})$ against $1 /$ [insulin] gave the $K_{\mathrm{M}}, k_{\text {cat }}$ and $k_{\text {cat }} / K_{\mathrm{M}}$ values were $3.7 \times 10^{-2} \mathrm{mM}, 1.2 \times 10^{-2} \mathrm{~min}^{-1}$, $3.1 \times 10^{1} \mathrm{~min}^{-1} \mathrm{mM}^{-1}$. Comparison of the $K_{\mathrm{M}}$ with that of Trx from other sources (Table 1) reveals that $T$. camphorata's $K_{\mathrm{M}}$ is several fold larger. The result indicating that the TcTrx works at higher substrate concentration. But the $k_{\text {cat }}$ value is similar to that of Trx from other sources.

\section{Properties of the purified TcTrx}

The TcTrx enzyme was shown to possess Trx activity by its ability to reduction insulin. Heat stability of the TcTrx was tested to examine the effect of heat on the Trx activity as described in the Materials and Methods. We found $80 \%$ and $40 \%$ residual activity when the enzyme was treated at $40^{\circ} \mathrm{C}$ and $50^{\circ} \mathrm{C}$ for $5 \mathrm{~min}$, respectively. The enzyme activity found at $25^{\circ} \mathrm{C}$ was defined as $100 \%$ activity. The enzyme $(1.0 \mu \mathrm{g})$ was further heated for various time intervals at $45^{\circ} \mathrm{C}$. The enzyme activity decreased as the heating time increased (Figure 5). The enzyme's half-life of deactivation was $13 \mathrm{~min}$ at $45^{\circ} \mathrm{C}$. In Figure 6, the TcTrx is most activity under $\mathrm{pH}$ 7.0.

\section{Conclusion}

A three dimensional structural model of $T$. camphorata Trx based on its TcTrx cDNA sequence. This study reported the first cloning and expression of an important reduction enzyme, TcTrx, from $T$. camphorata. The active form of the TcTrx has been successfully expressed in yeast. The enzyme possesses Trx activity and is capable of reduction of disulfide bonds during the formation of newly synthesized proteins.

The TcTrx has a higher $K_{\mathrm{M}}$ value (Table 1) therefore can work under higher substrate concentration. Its $k_{\text {cat }}$ value is compatible to that of Trx from another source. It is likely that the $\operatorname{Trx}$ is one of the enzymes responsible for reducing protein disulfide targets in T. camphorata.

\section{Abbreviations \\ Trx: Thioredoxin; IPTG: Isopropyl $\beta$-D-thiogalactopyranoside; SDS-PAGE: Sodium dodecyl sulfate-polyacrylamide gel electrophoresis; PBS: Phosphate buffer saline.}

\section{Competing interests}

The authors declare that they have no competing interests.

\section{Authors' contributions}

P-FH and Y-TC carried out the molecular genetic studies and biochemical studies. C-TL was an adviser to carry out the molecular genetic and biochemical studies. LW and Y-TC participated in drafting the manuscript. C-TL and LW drafted the manuscript and revised the manuscript. All authors read and approved the final manuscript.

\section{Acknowledgements}

This work was supported by the National Science Council of the Republic of China, Taiwan under grant MOST 103-2313-B-019 -006 to C-T. Lin.

\section{Author details}

${ }^{1}$ Department of Bioscience and Biotechnology and Center of Excellence for the Oceans, National Taiwan Ocean University, 2 Pei-Ning Rd, Keelung 202, Taiwan. ${ }^{2}$ Institute of Genomics and Bioinformatics, Agricultural Biotechnology Center, National Chung Hsing University, Taichung, Taiwan. ${ }^{3}$ Department of Chemistry, Western Illinois University, 1 University Circle, Macomb, IL 61455-1390, USA.

Received: 11 July 2014 Accepted: 21 November 2014 Published online: 04 December 2014

\section{References}

Ao ZH, Xu ZH, Lu ZM, Xu HY, Zhang XM, Dou WF (2009) Niuchangchih (Antrodia camphorata) and its potential in treating liver diseases. J Ethnopharmacol 121:194-212

Arnold K, Bordoli L, Kopp J, Schwede T (2006) The SWISS-MODEL workspace: a web-based environment for protein structure homology modeling. Bioinformatics 22:195-201 
Buchanan BB, Schurmann P, Decottignies P, Lozano RM (1994) Thioredoxin: a multifunctional regulatory protein with a bright future in technology and medicine. Arch Biochem Biophy 314:257-260

Chae HZ, Uhm TB, Rhee SG (1994) Dimerization of thiol-specific antioxidant and the essential role of cysteine 47. Proc Natl Acad Sci U S A 91:7022-7026

Chen CC, Ken CF, Wen L, Chang CF, Lin CT (2012) Taiwanofungus camphorata nitroreductase: cDNA cloning and biochemical characterization. Food Chem $135: 2708-2713$

Holmgren A (1979a) Reduction of disulfides by thioredoxin. Exceptional reactivity of insulin and suggested functions of thioredoxin in mechanism of hormone action. J Biol Chem 254:9113-9119

Holmgren A (1979b) Thioredoxin catalyzes the reduction of insulin disulfides by dithiothreitol and dihydrolipoamide. J Biol Chem 254:9627-9632

Holmgren A, Reichard P (1967) Thioredoxin 2: Cleavage with cyanogen bromide Eur J Biochem 2:187-196

Hsieh YH, Chu FH, Wang YS, Chien SC, Chang ST, Shaw JF, Chen CY, Hsiao WW, Kuo YH, Wang SY (2010) Antrocamphin A, an anti-inflammatory principal from the fruiting body of Taiwanofungus camphoratus, and its mechanisms. J Agric Food Chem 58:3153-3158

Huang JK, Ken CF, Huang HM, Lin CT (2007) Biochemical characterization of a novel 2-Cys peroxiredoxin from Antrodia camphorata. Appl Microbiol Biotechnol 74:84-92

Huang CY, Chen YT, Wen L, Sheu DC, Lin CT (2014) A peroxiredoxin CDNA from Taiwanofungus camphorata: role of Cys31 in dimerization. Mol Biol Rep 41:155-164

Ken CF, Hsiung TM, Huang ZX, Juang RH, Lin CT (2005) Characterization of Fe/Mn-superoxide dismutase from diatom Thallassiosira weissflogii: cloning, expression, and property. J Agric Food Chem 53:1470-1474

Ken CF, Chen HT, Chang RC, Lin CT (2008) Biochemical characterization of a catalase from Antrodia camphorata: Expression in Escherichia coli and enzyme properties. Bot Stud 49:119-125

Ken CF, Lin CY, Jiang YC, Wen L, Lin CT (2009) Cloning, expression and characterization of an enzyme possessing both glutaredoxin and dehydroascorbate reductase activity from Taiwanofungus camphorata. J Agric Food Chem 57:10357-10362

Ken CF, Chen IJ, Lin CT, Liu SM, Wen L, Lin CT (2011) Monothiol glutaredoxin CDNA from Taiwanofungus camphorata: A novel CGFS-type glutaredoxin possessing glutathione reductase activity. J Agric Food Chem 59:3828-3835

Ken CF, Chang CC, Wen L, Huang JK, Lin CT (2014) Biochemical characterization of a functional recombinant aryl-alcohol dehydrogenase from Taiwanofungus camphorata. Bot Stud 55(14):2-10

Li W, Churchich JE (1997) Activation of partially folded mitochondrial malate dehydrogenase by thioredoxin. Eur I Biochem 246:127-132

Liau YJ, Chen YT, Lin CY, Huang JK, Lin CT (2010) Characterisation of 2-Cys peroxiredoxin isozyme (Prx1) from Taiwanofungus camphorata (Niu-chang-chih): Expression and enzyme properties. Food Chem 119:154-160

Limacher A, Glaser AG, Meier C, Schmid-Grendelmeier P, Zeller S, Scapozza L, Crameri R (2007) Cross-reactivity and 1.4-Å crystal structure of Malassezia sympodialis thioredoxin (Mala s 13), a member of a new pan-allergen family. J Immunol 178:389-396

Obiero J, Pittet V, Bonderoff SA, Sanders DAR (2010) Thioredoxin system from Deinococcus radiodurans. J Bacteriol 192:494-501

Pieulle L, Stocker P, Vinay M, Nouailler M, Vita N, Brasseur Gl, Garcin E, Sebban-Kreuzer C, Dolla A (2011) Study of the thiol/disulfide redox systems of the Anaerobe Desulfovibrio vulgaris points out pyruvate: ferredoxin oxidoreductase as a new target for thioredoxin 1. J Biol Chem 286:7812-7821

Russel M, Mode P (1986) The role of thioredoxin in filamentous phage assembly. Construction, isolation, and characterization of mutant thioredoxins. J Biol Chem 261:14997-15005

doi:10.1186/s40529-014-0077-z

Cite this article as: Chen et al:: Molecular cloning and characterization of a thioredoxin from Taiwanofungus camphorata. Botanical Studies 2014 55:77.

\section{Submit your manuscript to a SpringerOpen ${ }^{\circ}$ journal and benefit from:}

- Convenient online submission

- Rigorous peer review

- Immediate publication on acceptance

- Open access: articles freely available online

- High visibility within the field

- Retaining the copyright to your article

Submit your next manuscript at $>$ springeropen.com 